\title{
RARE EARTH ELEMENTS GEOCHEMISTRY OF FLUORITE FROM THE MATO PRETO CARBONATITE COMPLEX, SOUTHERN BRAZIL
}

\author{
ROBERTO VENTURA SANTOS, MARCEL AUGUSTS DARDENNE \& \\ CLAUDINEI GOUVEIA DE OLIVEIRA
}

\begin{abstract}
RESUMO GEOQUÍMICA DE ELEMENTOS, TERRAS RARAS DE FLUORITAS DO COMPLEXO CARBONATíTICO DE MATO PRETO, PARANÁ Depósitos de fluorita no sul do Brazil associam-se em geral a rochas graníticas e sedimentares carbonáticas. O depósito de fluorita de Mato Preto constitui uma excessão urna vez que as encaixantes são carbonatitos e rochas alcalinas silicáticas. Este trabalho discute a origem das fluoritas de Mato Preto e mostra que elas apresentam um amplo espectro de razões $(\mathrm{La} / \mathrm{Lu})_{\mathrm{n}}$ : fluoritas com alta razão $(\mathrm{La} / \mathrm{Lu})_{\mathrm{n}}$ são relacionadas ao magmatismo alcalino; enquanto fluoritas com baixa razão $(\mathrm{La} / \mathrm{Lu})$, são relacionadas a contaminação por rochas encaixantes. Dados de isótopos de oxigênio, carbono e estrôncio mostram também que os carbonatitos de Mato Preto foram significativamente contaminados pelas rochas encaixantes.
\end{abstract}

Palavras-chaves: carbonatito, elementos terras raras, Mato Preto

ABSTRACT Fluorite deposits in Southern Brazil are usually associated to limestone and granitic rocks. The Mato Preto deposit fluorite is an exception because it occurs associated to carbonatite and alkaline silicate rocks. We discuss the origin of this deposit based on rare earth element (REE) geochemistry and show that fluorite from Mato Preto has an REE spectrum ranging from high to low $(\mathrm{La} / \mathrm{Lu})_{\mathrm{n}}$ ratios. We suggest that fluorite with high $(\mathrm{La} / \mathrm{Lu})_{\mathrm{n}}$ are related to the alkaline magmatism, whereas fluorite with intermediate to low $(\mathrm{La} / \mathrm{Lu})_{\mathrm{n}}$ did not derive from alkaline magmatism, but probably from the country rocks. This interpretation is supported by oxygen, carbon and strontium isotopes that show that the carbonatites are significantly contaminated by their country rocks.

Keywords: carbonatite, rare earth element, Mato Preto

INTRODUCTION Carbonatites have high concentration of REE, with values usually higher than $15000 \mathrm{ppm}$ (Cullers \& Medaris 1977). They also present high normalized $\mathrm{La} / \mathrm{Lu}$ ratios, indicating an enrichment of the LREE relative to the HREE (Balaskov \& Pozharitskaya 1965, Eby 1975, Cullers \& Medaris 1983, Hogarth et al. 1985). Fluorine enrichment have been described in the late stages of carbonatite evolution and, in particular, in shallow seated complexes (LeBas 1977, Jago \& Gittins 1991). Besides fluorite (CaF2), fluorine is also hosted by apatite and biotite which may have up to 3\% F (Deer et al. 1992). Large concentrations of fluorite associated with carbonatites were described in Amba Donga, India (Deans et al. 1973), and Okurusu (Van Zijl 1962). Similar to Mato Preto complex, these complexes exhibit strong potassic fenitization and potash-feldspar-bearing fenites.

Southern Brazil has several fluorite deposits, among which the most important are Mato Preto, Barra do Itapirapuã, Braz, Mato Dentro, Volta Grande, Lageado Grande and Sete Barras. Except for Mato Preto and Barra do Itapirapuã, these deposits are interpreted as related to either sedimentary-hydrothermal (Volta Grande and Lageado Grande) or hydrothermal (Lages) in origin. Mato Preto and Barra do Itapirapuã are related to alkaline carbonatite complexes.

This paper discusses the REE, oxygen and carbon isotope data of fluorite and country rocks from the Mato Preto fluorite deposit and aims to better understand the relationship the fluorite deposit and the alkaline magmatism.

\section{GEOLOGY OF THE MATO PRETO COMPLEX}

The Mato Preto complex is part of the Arco de Ponta Grossa alkaline province (Almeida 1983) (Fig. 1). The complex is emplaced along the Morro Agudo Fault Zone, which marks the contact between the Açunguí metasedimentary rocks and the Três Córregos granite (Fig. 2). The Morro Agudo fault zone, together with other regional structures, had an important role in the emplacement of the complex and the fluorite deposit.

The complex has approximately $24 \mathrm{~km}^{2}$ and consists of four circular structures, each measuring $1 \mathrm{~km}$ in diameter. The dominant rocks include fenitized syenites, phonolites, and carbonatites. K-Ar dating of phonolite dikes from the complex gave an age of 65 m.y. (Cordani \& Hasui 1969). The Mato Preto complex displays strong potassic fenitization in which the main products are potassic feldspar fenites derived from the syenites and country rocks, and glimerites from the phonolites and mafic rocks.

Carbonatites from Mato Preto occur as dikes, plugs or as the matrix of feldspatic breccias both of which intruded fenitized syenites and country rocks (Loureiro \& Tavares 1982, Jenkins 1987, Santos 1988, Santos \& Dardenne 1988, Santos et al. 1990). Santos (1988) described two main carbonatite generations: a) dolomite- to ankerite-bearing carbonatites commonly associated to feldspar clasts; and b) calcite-bearing carbonatites of the matrix of carbonatite breccias. These two carbonatite generations occur in the Clugger deposit and may not be recognizable in other parts of the complex.

Fluorite in Mato Preto occurs in four subparallel N50-60 E lenses dipping $80-85^{\circ} \mathrm{NW}$. The lenses measure $250 \times 80 \mathrm{~m}$ and are enveloped by hydrothermally altered phonolite and tinguaite dikes, both of which intrude the carbonatite and breccias (Jenkins 1987). Santos (1988) and Santos \& Dardenne (1988) described four main fluorite generations in the Mato Preto complex: black-purple fluorite, purple fluorite, colorless-microcrystaline fluorite, and remobilized fluorite. Among these generations, the black-purple is the only so far not described in the Clugger deposit.

\section{METHODS AND RESULTS Carbonatite samples} were defined as consisting of more than $50 \mathrm{wt} \%$ carbonate and having magmatic banding, magmatic flow structures and country rock xenoliths. They were collected in outcrops and drill cores of the fluorite mine. In general, they are mediumto coarse-grained. Metasomatic rocks usually occur close to the carbonatites and may or not preserve the original protolith texture.

REE and trace element data were obtained by plasma spectrometry at Geosol Laboratory, Belo Horizonte. Fluorite samples were selected according to their generations de- 


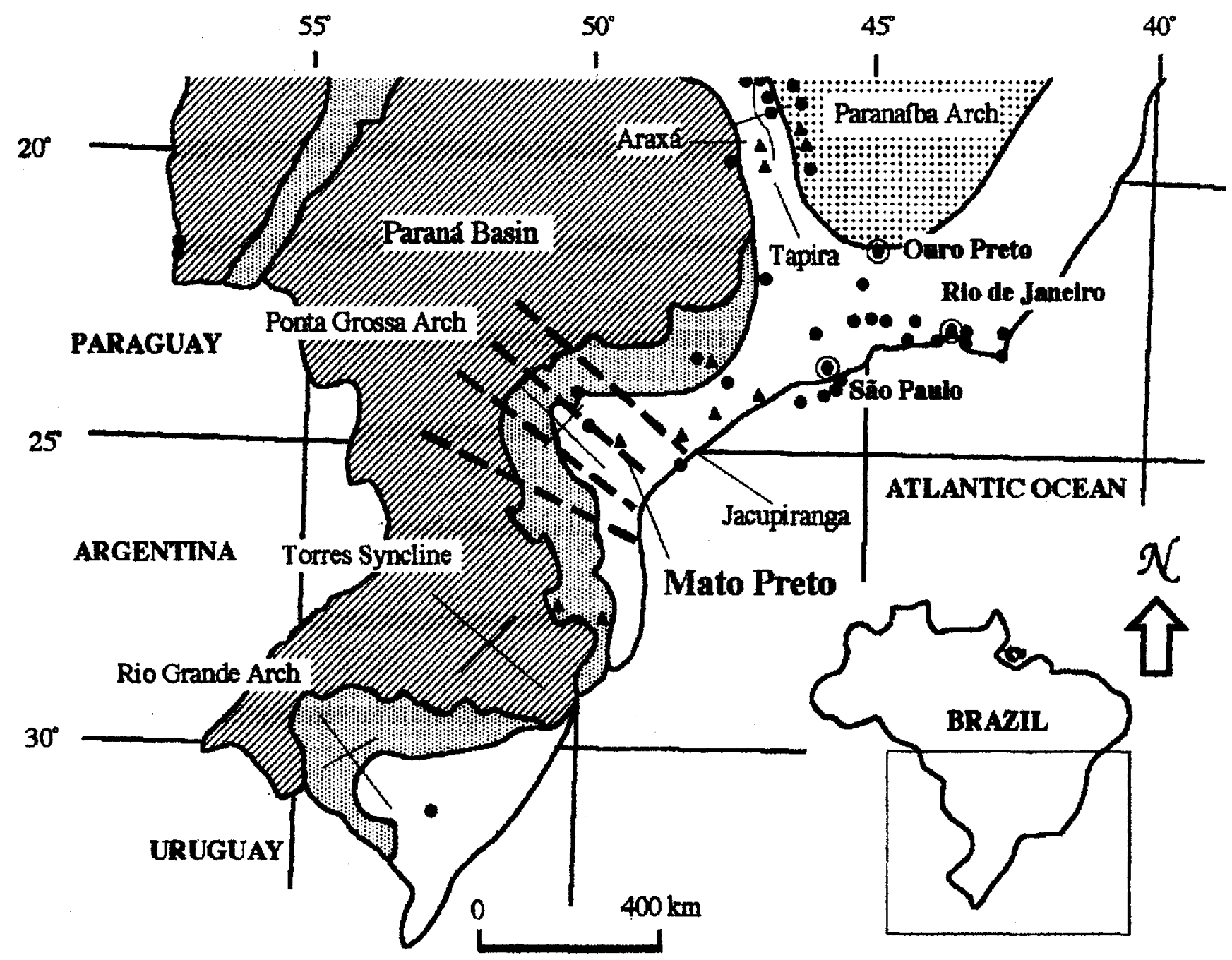

Undivided Pre-Braziliano to Mid Precambrian (Såo Francisco Craton).

$\square$ Pre-Devonian, mainly Precambrian Rocks.

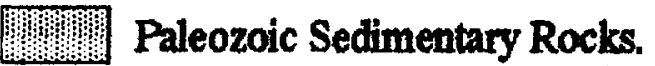

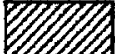

\section{Cretaceous Basaltic and Later Sedimentary Rocks.}

Figure 1 - Location of alkaline complexes in Central and Southern Brazil. From Ulbrich \& Gomes (1981).

Figura 1 - Localização dos complexos alkalinos no sul e centro do Brazil. Extraído de Ulbrich \& Gomes (1981).

scribed by Santos \& Dardenne (1988), i.e. black-purple, purple, colorless microcrystalline, and remobilized, from which the mineral was concentrated by means Franz magnetic separator and dense liquids.

The REE patterns of two carbonatites, a fenitized syenite, a phonolite, and a fenitized porfiritic granite of the Mato Preto complex show a remarkable enrichment of light REE (LREE) relative to heavy REE (HREE), and normalized ratio $\mathrm{La} / \mathrm{Lu}$ ranging between 2.52 and 3.66 (Table 1). The total content of REE increases in the following order: fenitized granite phonolite - fenitized syenite - carbonatite.
The fenitized porfiritic granite has a turbid potassic feldspar which replaces both quartz and older phases of feldspar. The REE pattern does not show Eu anomaly and has one of the largest $\mathrm{La} / \mathrm{Lu}$ ratio among the analyzed samples (Fig. 3). The phonolite and the fenitized syenite present total REE contents slight higher than the granite. The fenitized syenite is an equigranular rock which may be a more evolved fenitization product of the granite. The carbonatites have the highest concentration of total REE, with values ranging between 630 and $3007 \mathrm{ppm}$. The normalized $\mathrm{La} / \mathrm{Lu}$ ratio ranges between 


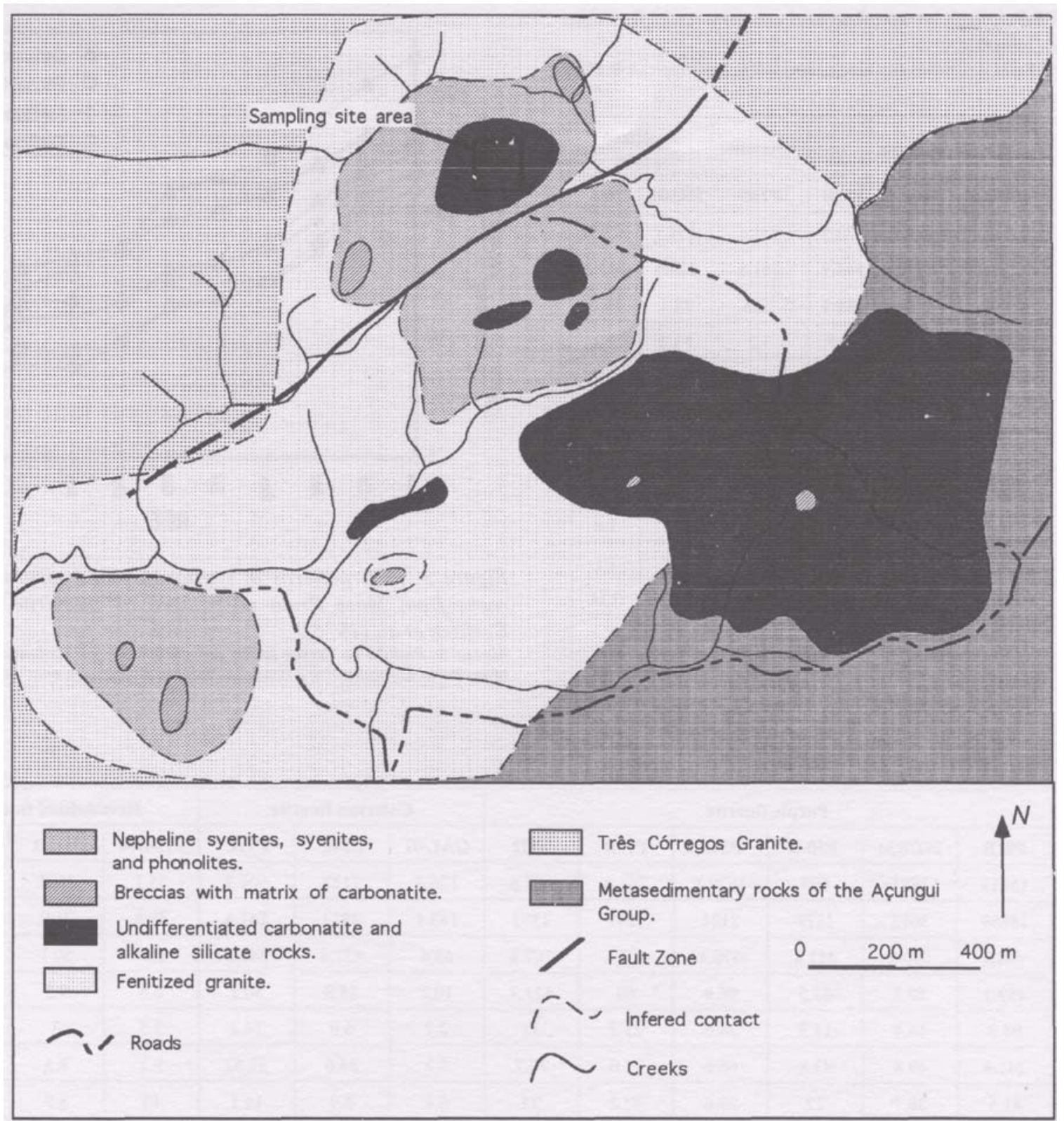

Figure 2 - Geologic map of the Mato Preto complex from Santos (1988).

Figura 2 - Mapa geológico do complexo de Mato Preto (Santos 1988).

2.38 and 3.66 (Table I), which is close to those observed in the previous rocks.

The REE data of the carbonatites are similar to those of the purple and the colorless microcrystaline fluorites (Fig. 4). The purple fluorite occurs as veinlets in the carbonatite and presents high contents of REE and high normalized $\mathrm{La} / \mathrm{Lu}$ ratios (2.01 to 2.52). Contrasting to the purple fluorite, textural evidence shows that the colorless microcrystaline fluorite replaces both the carbonate of the carbonatite and the purple fluorite. Its $\mathrm{La} / \mathrm{Lu}$ ratio ranges from 2.13 to 3.66 (Table 2). The remobilized fluorite generations present a wide spectrum of REE patterns in which normalized $\mathrm{La} / \mathrm{Lu}$ ratios are usually lower than those of older fluorite generations (0.78 to 2.93). One of the samples of remobilized fluorite presents a strong negative $\mathrm{Ce}$ anomaly and HREE enrichment.

DISCUSSION Fluorite from Mato Preto shows a general decrease in the total REE content from the earlier to the younger generation suggesting that the F-bearing solutions became progressively depleted in REE (Fig.4). Similar feature was observed in fluorites from other localities (Strong et al. 1984), and in particular, in Volta Grande and Sete Barras (Ronchi \& Dardenne 1987).

The REE patterns of the purple microcristaline fluorite from Mato Preto suggest that this generation is probably related to late magmatic fluids, as also suggested by petrographic studies and the association of this fluorite with REE minerals. The colorless microcrystaline fluorite occurs associated to strong hydrothermal alteration in which phonolite dikes and potassic-feldspar clasts within the carbonatite are transformed into clay mineral-bearing rocks. Thin section studies reveals that this fluorite replaces both the carbonates of the carbonatite and the pupple fluorite, suggesting that its REE patterns is probably inherited. This fluorite presents a wide range of $\mathrm{La} / \mathrm{Lu}$ ratio indicating a larger degree of remobilization if compared to the purple fluorite. The remobilized 
Tabela 1: REE data from alkaline and country rocks from the Mato Preto Complex.

Tabela 1: Terras Raras das rochas alcalinas e encaixantes do Complexo de Mato Preto

\begin{tabular}{|c|c|c|c|c|c|c|}
\hline \multirow{2}{*}{} & \multicolumn{4}{|c|}{ Carbonatite } & Phonolite & \multicolumn{2}{c|}{$\begin{array}{c}\text { Fenitized } \\
\text { syenite }\end{array}$} \\
\cline { 2 - 7 } & $\mathbf{1 0 D B 4 6}$ & $\mathbf{7 D B 4 6}$ & P95B & P26B & SR501 & P78 \\
\hline La & 187 & 935.3 & 333.5 & 101.5 & 154.7 & 73.3 \\
\hline Ce & 278.1 & 1392 & 544.9 & 161.8 & 229.5 & 141.3 \\
\hline Nd & 107.6 & 496.5 & 218.9 & 52.3 & 75.1 & 41.6 \\
\hline Sm & 15.9 & 79.6 & 39.8 & 7.2 & 13.2 & 7.3 \\
\hline Eu & 3.8 & 20.2 & 11.3 & 2 & 4.1 & 1.9 \\
\hline Gd & 10.1 & 51.1 & 30.5 & 5.5 & 11.8 & 5.8 \\
\hline Dy & 8.1 & 20.4 & 21.8 & 3.6 & 7.4 & 3.4 \\
\hline Ho & 1.8 & 3.3 & 4 & 0.65 & 1.3 & 0.48 \\
\hline Er & 4.8 & 6.4 & 9.4 & 2 & 3.7 & 1.6 \\
\hline Yb & 2.7 & 2 & 4 & 1.95 & 1.9 & 1.1 \\
\hline Lu & 0.3 & 0.25 & 0.4 & 0.3 & 0.21 & 0.14 \\
\hline $\mathbf{Y}$ & 96 & 168 & 260 & 24 & & \\
\hline (La/Lu)n & 2.52 & 3.66 & 2.38 & 2.63 & 2.87 & 3.42 \\
\hline
\end{tabular}

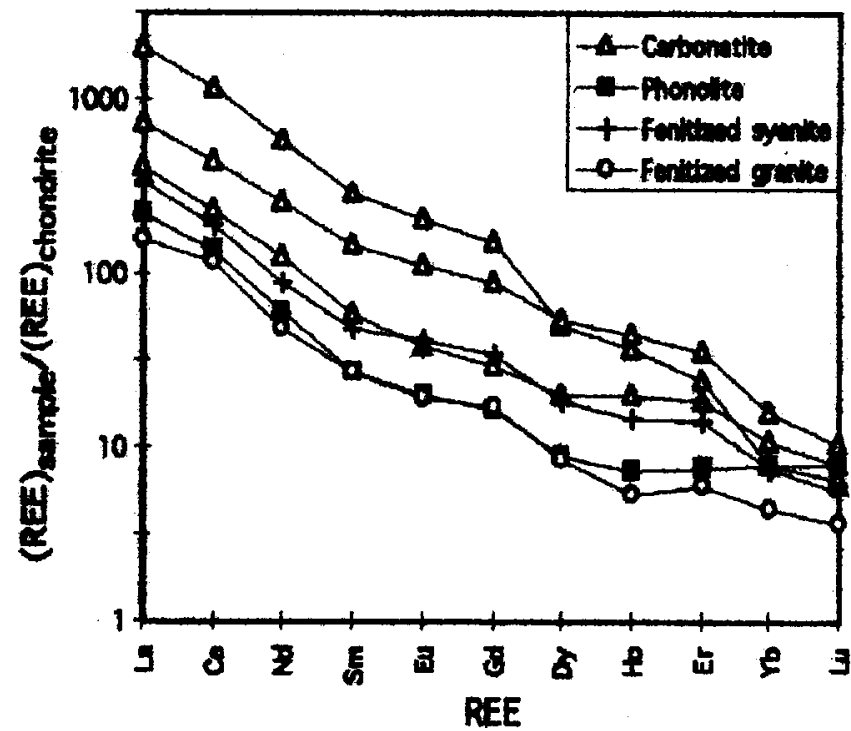

Figure 3. REE patterns of carbonatite and alkaline silicate rocks from Mato Preto normalized to chondrite values of Evensen et al. (1978).

Figura 3: Padrão de Terras Raras dos carbonatitos e rochas silicáticas de Mato Preto normalizados a conduto, valores de Evensen et al. (1978).

Table 2: REE data offluorites from Mato Preto.

Tabela 2: Terras Raras das fluoritas de Mato Preto.

\begin{tabular}{|c|c|c|c|c|c|c|c|c|c|c|c|c|}
\hline & \multicolumn{6}{|c|}{ Purple fluorite } & \multicolumn{3}{|c|}{ Colorless fluorite } & \multicolumn{3}{|c|}{ Remobilized fluorite } \\
\hline & P81B & $29 D B 34$ & P30A & P34B & P70B & TH2 & GAL 01 & P34C & P71C & $71 \mathrm{DB} 60$ & P71D & T1C \\
\hline $\mathbf{L a}$ & 15113 & 2881 & 699 & 1670.1 & 761.8 & 832.6 & 126.3 & 2122 & 501.3 & 55.1 & 3501 & 15.8 \\
\hline $\mathrm{Ce}$ & 18869 & 3017 & 1178 & 2121 & 1241 & 1573 & 183.1 & 2522 & 841.5 & 79.8 & 21.9 & 28.1 \\
\hline Nd & 4416 & 550.2 & 411.8 & 670.4 & 407.6 & 707.8 & 65.4 & 421.4 & 349.3 & 32.4 & 50.1 & 26.1 \\
\hline Sm & 453.1 & 59.3 & 67.5 & 96.9 & 69 & 121.3 & 10.2 & 35.8 & 50.2 & 6.8 & 9.5 & 7.9 \\
\hline $\mathbf{E u}$ & 94.3 & 14.4 & 17.3 & 24.6 & 21.3 & 32 & 2.7 & 6.9 & 14.2 & 2.5 & 3 & 3.3 \\
\hline Gd & 241.4 & 49.8 & 43.8 & 66.6 & 71.6 & 70.7 & 7.2 & 24.6 & 31.52 & 9.1 & 8.5 & 11.7 \\
\hline Dy & 81.5 & 38.7 & 27 & 29.6 & 47.2 & 33 & 6.4 & 8.9 & 14.1 & 13 & 8.9 & 25.5 \\
\hline Ho & 17.4 & 6.8 & 4.8 & 5.1 & 6.9 & 6.3 & 1.3 & 1.92 & 2.6 & 2.7 & 1.9 & 6.5 \\
\hline $\mathbf{E r}$ & 38.7 & 16.6 & 12.3 & 11.9 & 13.7 & 15.9 & 3.9 & 4.7 & 5.4 & 7.8 & 5.7 & 24.2 \\
\hline $\mathbf{Y b}$ & 15.4 & 12 & 9.6 & 7.3 & 6.6 & 9.7 & 3.5 & 2.5 & 2.4 & 7.9 & 5.3 & 22.7 \\
\hline $\mathbf{L u}$ & 1.7 & 1.5 & 1.2 & 0.85 & 0.79 & 1.09 & 0.43 & 0.43 & 0.29 & 1.02 & 0.72 & 2.7 \\
\hline $\mathbf{Y}$ & 3360 & 520 & 440 & 392 & 520 & 840 & 168 & 164 & 200 & 280 & 368 & 164 \\
\hline (La/Lu)n & 2.52 & 2.26 & 2.01 & 2.43 & 2.26 & 2.05 & 2.13 & 3.66 & 3.09 & 1.39 & 2.93 & 0.78 \\
\hline
\end{tabular}

fluorite displays a more heterogeneous REE patterns and an enrichment of HREE relative to LREE if compared to other fluorite generations. For instance, the remobilized white fluorite displayed in Figure 4 presents a negative Ce anomaly that was not observed in other fluorites, indicating that it formed under more oxidizing conditions than other fluorite generations.

Constraints on the nature of the fluorine mineralizing solutions The nature of the fluorine-rich solutions in Mato Preto is not well constrained, despide evidences that both fluorine and carbonate complexes were important. Fluorine-rich solutions are usually accompanied by argilization and silicification, conspicous during the formation of the colorless microcrystaline fluorite. Purple and remobilized fluorite have evidences, such as carbonate solid and fluid inclusions, that the REE were transported by solutions saturated in carbonate complexes (Santos 1988). In many instances, the fluid inclusions may have evolved from the solid inclusions.

Fluorine in Mato Preto may be related both to magmatic and non-magmatic fluids. The high REE concentration in 


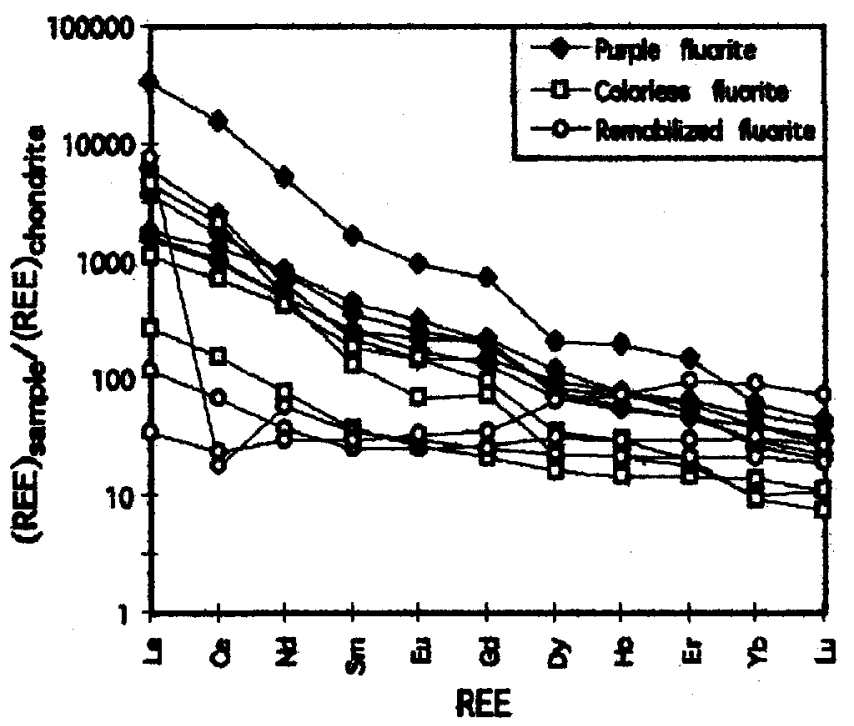

Figure. 4: REE patterns of fluo rite from Mato Preto normalized to chondrite concentrations given by Evensen et al. (1978). Figura 4: Padrão de Terras Raras de fluorita de Mato Preto normalizados a valores de condrito de Evensen et al. (1978).

fluorite and in its host rocks (Fig. 3 and 4) suports a magmatic origin for at least the purple variety. Although the colorless microcristaline fluorite has a REE patterns that is similar to the purple fluorite, field evidences suggest that it formed under hydrothermal conditions and by fluids that are not clearly related to the magmatism.

Carbon, oxygen and strontium isotope data indicate that carbonatites from Mato Preto underwent large-scale country rock contamination, suggesting that part of fluorine may derive from the country rocks. Oxygen and carbon isotope data from Santos et al. (1989) and Santos \& Clayton (1995) indicate that, although country rock contamination played an important role in the evolution of the carbonatites, a better understanding of the process requires a detailed study of both carbonate and silicate rocks from this complex. Nevertheless, Figure 5 illustrates the effects of limestone contamination of alkaline melts through the oxygen and carbon data of the Mato Preto Complex. Despide the limited application of the model to Mato Preto, it shows that contamination by limestone from the country rock may have significantly affected the isotopic composition of its carbonatites.

Country rock contamination has also been invoked by Ronchi et al. (1993) to explain ${ }^{87} \mathrm{Sr} /{ }^{86} \mathrm{Sr}$ ratio of two ore samples from Mato Preto. These samples present ${ }^{87} \mathrm{Sr} /$ ${ }^{86} \mathrm{Sr}$

ratio of 0.70544 and 0.78394 indicating that the region of fluorite may also have been affected by crustal contamination. Among the deposits studied by the Authors, fluorite from Mato Preto presents the widest range in ${ }^{87} \mathrm{Sr} /{ }^{86} \mathrm{Sr}$ ratio.

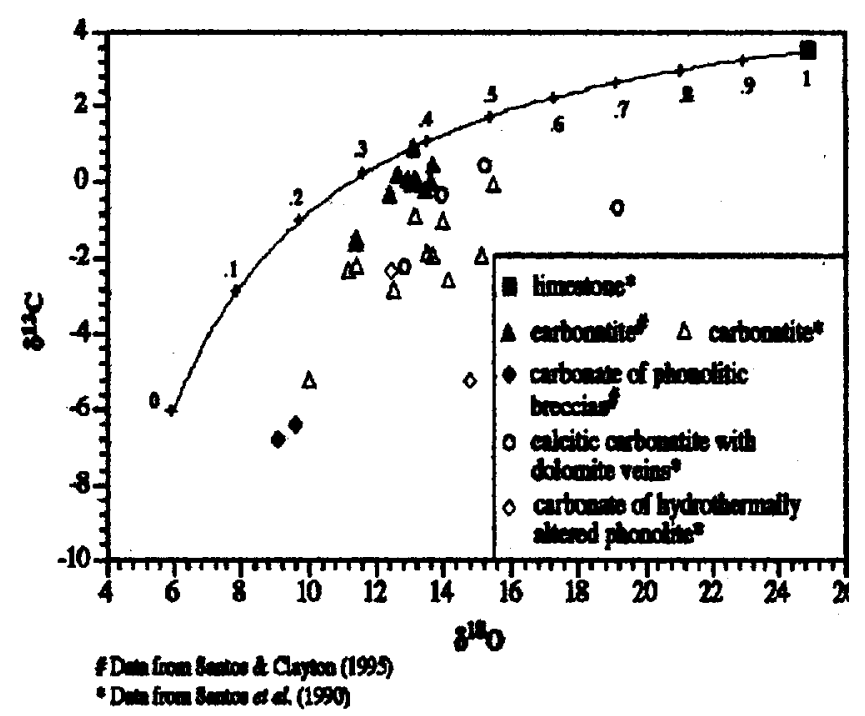

Figure - 5. Diagram showing the $\delta^{18} O$ and $\delta^{13} C$ of samples

from Mato Preto, as well as a mixing line which models the contamination of a carbonatite-silicate melt by limestone, assuming that the uncontaminated magma consists of $70 \%$ silicates and has $\delta^{18} O$ and $\delta^{13} C$ of $6.0 \%$ and $6.0 \% \mathrm{o}$

respectively, and that the limestone has ô $O$ and ô $\mathrm{C}$ of $25.0 \%$ oand $3.5 \%$ o, respectively. The numbers along the mixing line represent limestone fraction in the mixture. Figura 5 - Diagrama de $\&^{18}$ Oversus $\mathrm{S} C$ de amostras de carbonato dos carbonatitos de Mato Preto, mostrando curva de mistura entre magma silicático-carbonatítico contaminado por calcário. Para a construção da curva, assumiu-se que o magma silicático-carbonatítico consiste de $70 \%$ de silicatos e $8^{18} \mathrm{O}$ e $5^{13} \mathrm{C}$ iguais a $6.0 \%$ e e-6.0\%, respectivamente. Para a composição isotópica do calcário assumiu-se valores de $\delta^{18} O$ e $\delta^{13} C$ de $25.0 \%$ e e $3.5 \%$, respectivamente. Os números ao longo da curva representam a fração de calcário na mistura.

CONCLUDING REMARKS The evolution of fluorite in Mato Preto complex has a close association with carbonatites, which in part explains its high REE contents. The earlier generation of fluorite has unique REE content and pattern, marked by a strong enrichment in LREE relative to HREE, as compared to fluorite not associated to carbonatite. However, younger fluorite generations are silimar to fluorites from metasedimentary and hydrothermal deposits, suggesting that part of the fluorine in Mato Preto was not derived from the alkaline magmatism. In this regard, carbon, oxygen and strontium isotopes show that the carbonatites from Mato Preto were significantly contaminated by the country rocks.

ACKNOWLEDGMENTS We thank Prof. José Carlos Gaspar for the suggestions and critical review of this paper.

\section{REFERENCES}

ALMEIDA, F.F.F. 1983. Relações tectônicas das rochas alcalinas mesozóicas da região meridional da Plataforma Sul-Americana. Rev. Bras, de Geoc., 13(3)139-158.

BALASHOV, U. A.\& POZHARITSKAYA, L.K. 1968. Fators governing the behaviour of rare-earth elements in the carbonatite process. Geochim. Int., 5:271-288.
CORDANI, V.G.\& HASUI, Y. 1968. Idades de K-Ar das rochas alcalinas do primeiro Planalto do Estado do Paraná. In: Cong. Bras. Geologia, 1968, Ouro Preto. Anais...Ouro Preto, SBG, p. 149-153.

CULLERS, R. N.\& MEDARIS, G.Jr. 1977. Rare earth elements in carbonatites and cogenetic alkaline rocks: examples from Seabrook Lake and Calendar Bar, Ontario. Contrib. Min. Petrol., 65:143-153. 
DEANS, T.; SUKHESWALA, R.W.; SITWA, S.F.\& VILADKAR, S.G. 1972. Metasomatic feldspar rocks (potash fenites) associated with the fluorite deposits and carbonatites of Amba Donga, Gujarat, India. Trans. Inst. Min. Metall, Sect. B, Vol. 81, p. B1-10.

DEER, W.A.; HOWIE, R.A. \& ZUSSMAN, J. 1992. An Introduction to the Rock-Forming Minerals. Longman Scientific \& Technical, Hong Kong, $2^{\circ}$ Ed., p. 696.

EBY, G.N. 1975. Abundance and distribution of the rare-earth elements and Ytrium in the rocks and minerals of the Oka Carbonatite Complex, Quebec. Geochim. Cosmochim. Acta, 39(5):597-620.

EVENSEN, N.M.; HAMILTON, P.J. \& O'NIONS, R.K. 1978. Rare-earth abundances in chondritic meteorites. Geochim. Cosmoch. Acta, 42:1199-1212.

HOGARTH, D.D.; HARTREE R. \& LOOP, J. 1985. Rare-earth element minerals in four carbonatites near Gatineau, Ontario. Am. Min., $70: 1135-1142$

JAGO, B.C.\& GITTINS, J. 1991. The role of fluorine in carbonatite magma evolution. Nature 239(3):56-58

JENKINS, R.E. 1987. Geology of the Clugger-Fluorite Deposit, Mato Preto, Paraná, Brazil. Rev. Bras, de Geoc., 17(3):288-294.

LEBAS, M.H. 1977. Carbonatite-nephelinite volcanism: An African History. Wiley-Interscience, New York, p. 347.

LOUREIRO, F.E.L. \& TAVARES, J.R. 1983. Duas novas ocorrências de carbonatitos: Mato Preto e Barro do Itapirapuã. Rev. Bras, de Geoc., 13(1):7-11.

RONCHI, L.H. \& DARDENNE, M.A. 1987. Padrão geoquímico de elementos terras raras dos depósitos de Sete Barras e Volta Grande PR. In: Cong. Bras. Geoquimica, 1987, Porto Alegre. Anais...Porto Alfím-e SRfin vol 1 n 17-23
RONCHI, L.H.; TOURAY, J C; DARDENNE, M.A.; PIMENTEL, M.M. 1993. Preliminary ${ }^{87} \mathrm{Sr} / \mathrm{Sr}$ systematics in fluorite deposits ores from different deposits types in Vale da Ribeira District (Southern Brazil). Extended Abstract Submitted to 2nd Biennial SGA Meeting - Granada, Spain, p. 180-185.

SANTOS, R.V. 1988. Geologia e Geoquímica do Depósito de Fluorita do Complexo Alcalino Carbonatíüco de Mato Preto -Paraná. Diss. de Mestrado, Univ. de Brasília, p. 144.

SANTOS, R.V. \& CLAYTON, R.N. 1995. Variations of oxygen and carbon isotopes in carbonatites: A study of Brazilian alkaline complexes. Geochim. Cosmochim. Acta, 59(7):1339-1352.

SANTOS, R.V.\& DARDENNE, M.A. 1988. Fluorita de Mato Preto: um caso particular de fluorita associada a complexo alcalino carbonatítico. In: Cong. Bras. Geol., 35, Belém, 1988. Anais ... Belém, SBG, v. 3, p. 1251-1261.

SANTOS, R.V.; DARDENNE, M.A. \& MATSUI, E. 1990. Geoquímica de isótopos de carbono e oxigênio dos carbonatitos do Complexo Alcalino de Mato Preto, Paraná, Brasil Rev. Bras. Geoc., (1-4): 153-158.

STRONG, D.F.; FRYER, B.J. \& KERUCK, R. 1984. Genesis of the St. Lawrence fluorspar deposits as indicated by fluid inclusion, rare earth element, and isotopic data. Econ. Geol., 79:1142-1158.

ULBRICH, H.H.G.J. \& GOMES C.B. 1981. Alkaline rocks from continental Brazil. Earth Sci. Rev., 17:135-154.

VAN ZIJL, P. J. 1962. The geology structure and petrology of the alkaline intrusions of Okalkfeld and Okurusu and the invaded Damara rocks. Ann. Univ. Stell., vol. 37, Series A, n. 4, p. 241-324.

MANUSCRITO A861

Recebido em 11/11/96

Revisão dos autores em 20 de dezembro de 1996 Revisão aceita em 23 de dezembro de 1996 